\title{
A Comparative Study of Chunking Skills in Bilingual Children and Monolingual Children with and without Specific Language Impairment
}

\author{
Yunju Cho, Dongsun Yim \\ Department of Communication Disorders, Ewha Womans University, Seoul, Korea
}

Correspondence: Dongsun Yim, PhD Department of Communication Disorders, Ewha Womans University, 52 Ewhayeodae-gil, Seodaemun-gu, Seoul 03760, Korea Tel: $+82-2-3277-6720$

Fax: $+82-2-3277-2122$

E-mail: sunyim@ewha.ac.kr

Received: December 24, 2019

Revised: February 6, 2020

Accepted: February 6, 2020

This work was supported by the Ministry of Education of the Republic of Korea and the National Research Foundation of Korea (NRF2018S1A3A2075274)

\begin{abstract}
Objectives: This study investigates the differences in linguistic and nonlinguistic chunking skills between Korean-English bilingual children and Korean monolingual children with and without specific language impairment. Methods: A total of 64 children (Mono TD $=22$, Mono $S L I=16, B I T D=26$ ) between 4 to 6 years of age participated in this study. Linguistic chunking skills were assessed by wordlist recall task. Nonlinguistic chunking skills were assessed by symmetric-asymmetric matrix task. Results: There were significant main effects in group, condition type, and span in both the symmetric-asymmetric matrix task and Korean word list recall task. Also, there were significant main effects in word order, and span in the English word list recall task. Among the tasks, word order conditions in wordlist recall task were correlated with vocabulary skills of Mono TD, whereas Mono SLI showed correlation between conditions in symmetric-asymmetric matrix task and their vocabulary skills. BI TD showed relatively lower correlation between language ability and chunking skills compared to Mono TD. Conclusion: Children with SLI had difficulty in utilizing the chunking ability efficiently compared to Mono TD and BI TD in both linguistic and nonlinguistic chunking tasks. The episodic buffer to integrate working memory, long-term memory and language processing systems appears to be lower in SLI. However, there were no significant differences between Mono TD and BI TD. Since the episodic buffer reflects the language-based processing ability, TD groups' chunking skills were not affected by the bilingualism.
\end{abstract}

Keywords: Chunking, Chunking skills, Episodic buffer, Working memory, Bilingual, Specific language impairment

\begin{abstract}
국내에서 영어를 사용하는 인구가 늘어나고, 최근 아동의 조기 영어교육이 확대됨에 따라 가정에서 사용하는 언어와 학교환경에 서 사용하는 언어가 서로 다른 이중언어아동이 증가하고 있다. 이 에 한국어와 영어를 사용하는 이중언어아동의 언어 습득 및 발달 에 대한 관심이 증가하고 있다. 이중언어아동은 출생 직후 모국어 와 제2언어를 동시에 습득하는 동시적(simultaneous) 이중언어와, 모국어를 먼저 습득하고 3 세 이후 제 2 언어에 노출되어 습득하는 순차적(sequential) 이중언어로 분류된다(Kohnert, 2010).

이중언어아동의 언어 습득은 두 개 이상의 언어로 분산됨에 따 라, 단일언어아동의 언어 습득과 비교하여 더 큰 변동성(variabili-
\end{abstract}

ty)을 보이게 된다(Kan \& Kohnert, 2005). 이들은 단일언어를 사용 하는 아동과는 다른 언어발달 과정, 즉 언어 손실(language loss), 언어 간섭(interference), 언어 코드전환(code switching), 중간언어 (interlanguage)와같은 언어현상을 경험하게 된다(Hong, S. \& Yim, 2014). 이러한 이중언어아동의 특징은 정상적이며 흔히 발견되지 만, 이와 같은 특징으로 인해 이들의 언어적 능력을 한 가지 언어로 만 평가할 경우 낮은 수행도를 보여 단순언어장애아동과 수행도가 부분적으로 겹치는(overlap) 경우가 발생한다(Boerma, Wijnen, Lesema, \& Blom, 2017; Kohnert, 2008, 2010). 이에 단일언어아동과 는 다른 언어발달과정을 보이는 이중언어아동의 언어적 특성이 두 
가지 이상의 언어를 동시에 배우는 과정에서 나타나는 현상인지, 아니면 언어 기저의 어려움으로 인한 언어발달지연의 현상인지를 확인할 필요가 있다(Kohnert, 2008, 2010).

선행연구에 따르면 한 가지 언어로만 아동의 어휘 능력을 측정할 경우, L1과 L2에 노출된 시기와 언어 학습기간, 아동의 연령 등에 따라 이중언어아동이 단일언어아동과 비교해 더 낮은 점수를 보일 수 있다고 보고되었다(Bialystok, Luk, Peets, \& Yang, 2010; Lese$\operatorname{man}, 2000)$. 특히, 표준화된 언어검사로 순차적 이중언어 일반아동 의 L2를 평가했을 때에는, 정상적인 언어발달을 보이는 일반아동임 에도 불구하고, 단일언어 단순언어장애아동과 수행도가 부분적으 로 겹치는, 즉 두 집단 간의 상당한 부분적 일치(overlap)가 확인되 었다(Hakansson \& Nettelbladet, 1996; Paradis, Crago, Genesee, \& Rice, 2003; Windsor, Kohnert, Loxtercamp, \& Kan, 2008). 이는 단 순히 한 가지 언어로 어휘를 묻지 않고, L1과 L2 모두로 아동이 갖 고 있는 어휘의 개념(concept)을 평가하는 합산 점수법(conceptual scoring)의 필요성이 강조되는 이유이다. 이처럼 이중언어아동과 단순언어장애아동이 유사한 수행도를 보일 수 있는 것은, 언어는 축적되고 획득된 지식에 의존하는 고도의 경험의존적인 능력이기 때문이다(Windsor et al., 2008). 표준화된 언어검사도구는 단일언 어를 사용하는 또래아동을 기준으로 비교 규준이 설계되었기 때 문에 이는 아동이 그 검사언어를 경험하거나 사용한 정도에 따라 크게 좌우되며, 앞서 기술한 부분적 일치가 나타날 수 있다(Campbell, Dollaghan, Needleman, \& Janosky, 1997; Kohnert, Windsor, \& Yim, 2006). 이에 표준화된 검사뿐만 아니라 다양한 언어적, 비언 어적 과제를 통해 언어발달 기저의 능력을 평가하는, 즉 비표준화 된 검사도구를 사용하여 이중언어아동의 언어발달과정을 평가하 려는 시도가 활발하게 보고되고 있다(Boerma et al., 2017; Dollaghan \& Campbell, 1998; Welsh \& Pennington, 1988).

본 연구는 기존 Baddeley와 Hitch (1974)의 3요인 작업기억 모델 에 네 번째 요소로 일화적 완충기(episodic buffer)가 추가된 Baddeley (2000)의 4요인 작업기억 모델을 기반으로 한다. Baddeley (2000)에 따르면, 작업기억은 세 가지 하위체계와 이로부터 전달된 정보를 통합 및 조정하는 상위체계 중앙집행기능(central executive)으로 구성되어 있다. 하위체계에는 음운적 작업기억을 담당하 는 음운 루프(phonological loop), 시공간적 작업기억을 담당하는 시공간 스케치패드(visuospatial sketchpad), 단기기억과 작업기억 을 통합하여 시각적, 구어 청각적 정보를 결합하는 일화적 완충기 가 있다.

즉, 일화적 완충기는 Baddeley (2000)가 제안한 작업기억 모델의 하위요소 중 하나로 작업기억과 장기기억, 그리고 중앙집행기능의
하위시스템 간의 인터페이스를 형성하는 임시 다차원적 저장소로 여겨지며, 주요기능은 서로 다른 정보소스를 묶어 하나의 통합된 덩이(chunk)를 형성하는 덩이짓기(chunking) 기능을 담당한다 (Baddeley, Allen, \& Hitch, 2009). 이에 일화적 완충기의 용량(capacity)은 보유할 수 있는 일화(episode) 또는 덩이의 수에 의해 제 한되는 것으로 가정된다(Baddeley et al., 2009). 덩이는 장기기억과 의 상호작용으로 생기는 단기기억에서의 용량 단위로 여겨진다 (Cowan, 2001; Miller, 1956). 이를 바탕으로 덩이짓기 능력은 개인 이 처음에 접하는 서로 다른 정보 항목(item)을 묶어, 더 적고 통합 된 단위로 처리할 수 있도록 도와주는 주요기능으로(Montgomery, Evans, Fargo, Schwartz, \& Gillam, 2018), 단어 또는 숫자와 같 은 여러 항목을 하나의 표상으로 통합하여 개인의 저장 용량을 확 장하는 역할을 한다(Nobre et al., 2013).

최근 많은 선행연구에서는 일화적 완충기의 존재와 그 능력을 측정하기 위한 연구가 활발히 진행되고 있다(Alloway, Gathercole, Willis, \& Adams, 2004; Becker \& McGregor, 2016; Boyle, Lindell, \& Kidd, 2013; Petruccelli, Bavin, \& Bretherton, 2012). 그 중 문장 따라말하기는 음운적 정보와 의미론적, 구문적 정보를 통합하는 것을 필요로 하기 때문에, 언어 기저의 능력을 측정하며, 작업기억, 장기기억 그리고 언어 처리시스템을 통합하는 일화적 완충기를 측 정하는데 적합하다고 여겨진다(Petruccelli et al., 2012). 또한 이 과 제는 4 세 아동부터 성인에 이르기까지 다양한 대상자에게 실시하 기 적합하다고 보고되었다(Alloway et al., 2004).

특히 Baddeley et al. (2009)의 연구에서는 일화적 완충기의 존재 와 덩이짓기 능력을 확인하기 위해 문장폭 기억과제(constrained sentence span)를 문장 순과 무선 순 배열로 설정하였다. 덩이짓기 는 장기기억과의 상호작용으로 인해 형성되기 때문에, 각 개인의 장 기기억 차이를 통제하기 위하여 무선 배열 조건과 문장 순서의 배 열 조건을 구성하였다. 그 결과, 무선 배열과 비교해 문장 배열에서 더 높은 수행력을 보임에 따라 문장 순서의 배열 조건이 덩이짓기 를 통해 단기기억 용량에서 이익을 얻었다고 보았다.

선행연구에 따르면, 단순언어장애아동은 일반아동과 비교하여 낮은 문장 따라말하기 수행력을 보인다고 보고되었다(Ahn \& Kim, 2000; Laws \& Bishop, 2003). 이는 단순언어장애아동이 새로운 정 보가 입력된 단기기억과 기존의 의미적, 구문적 지식이 입력된 장기 기억을 통합하는 데 어려움을 보이기 때문에 일화적 완충기를 측 정하는 덩이짓기 과제에서 일반아동과 비교하여 더 낮은 수행을 보 이는 것으로 해석된다(Chun \& Yim, 2017; Becker \& McGregor, 2016; Petruccelli et al., 2012). 한편, 단일언어와 이중언어 일반아동 을 대상으로 실시한 문장 따라말하기 과제에서는 두 집단 간 수행 
력에 유의한 차이가 나타나지 않았다는 선행연구 결과가 보고되었 다(Gutié.rrez-Clellen, Restrepo, \& Simó.n-Cereijido, 2006; Ziethe, Eysholdt, \& Doellinger, 2013).

문장 따라말하기가 언어적 영역의 덩이짓기 능력을 평가하는 보 편적인 과제라면, 비언어적 영역에서는 다양한 시각적 과제가 일화 적 완충기의 덩이짓기 능력을 측정하기 위해 시도되고 있으며, 순서 에 대한 시공간 기억폭 회상 과제가 그 중 하나이다(Allen, Baddeley, \& Hitch, 2006; Baddeley et al., 2011; Huntley, Bor, Hampshire, Owen, \& Howard, 2011). 앞선 문장 따라말하기 과제에서 무선 배열 조건 과 문장 순 배열 조건으로 구분하여 덩이짓기 능력의 효율성 차이 를 확인한 바와 같이, 만약 시공간 기억폭 회상 과제에서도 대칭 조 건과 비대칭 조건으로 구분하여 자극을 제시한다면 덩이짓기 능력 의 효율성이 언어적 영역뿐만 아니라 비언어적인 시각적 영역에서 도 통용될 수 있는지 설명할 수 있을 것이다.

선행연구에 따르면, 시공간 작업기억 능력을 측정하는 비언어적 과제에서 또한 단순언어장애아동은 일반아동과 비교하여 낮은 수 행력을 보여, 언어적인 영역뿐만 아니라 비언어적인 영역에서도 작 업기억의 결함이 나타난다고 보고되었다(Lisa \& Gathercole, 2006; Montgomery, 1993; Poppen, Stark, Eisenson, Forrest, \& Wertheim, 1969). 한편, 이중언어 사용유무에 상관없이 단일언어와 이중언어 일반아동은 비언어적 시각적 과제 처리 수행에서 유의한 차이가 나 타나지 않았다(Kohnert \& Windsor, 2004; Windsor et al., 2008).

이에 본 연구는 일화적 완충기를 측정하는 과제로 언어적, 비언 어적 덩이짓기 과제를 사용하고자 한다. 언어적 덩이짓기 과제인 단 어목록회상의 경우 문장어순과 무선어순으로 나누어 일화적 완충 기의 덩이짓기 능력을 비교하고자 한다. 즉, 새로운 정보가 입력된 단기기억과 기존의 의미적, 구문적 지식이 입력된 장기기억을 통합 해야 하는 과제를 통해 낮은 덩이짓기 능력을 보이는 단순언어장애 아동 집단뿐 아니라, 단일언어아동과는 다른 언어적 발달과정을 겪는 이중언어 일반아동에게 실시하였을 때 어떤 양상을 보일지 확인하고자 한다. 정상발달을 보이는 이중언어 일반아동의 경우, 표준화된 언어검사에서 단일언어 단순언어장애아동과 수행도가 부분적으로 겹칠 가능성이 보고되었지만, 언어 기저의 처리과정을 반영하는 문장 따라말하기 과제에서는 두 집단 간 수행력에 유의 한 차이가 나타나지 않았다는 선행연구 결과가 보고되었기 때문이 다. 또한 언어적 덩이짓기 능력이 언어 기저의 처리과정을 반영한다 면, 아동이 사용하는 L1뿐만 아니라 L2에서도 그 능력과 양상이 확 인되어야 하기 때문에, $\mathrm{L} 1$ 인 한국어 단어목록회상에서 확인되는 일화적 완충기의 덩이짓기 능력과 그 양상이 L2인 영어 단어목록 회상 과제에서도 나타나는지 확인해보고자 한다.
또한, 언어적 요소가 배제된 비언어적 영역을 측정하는 비언어적 덩이짓기 과제 대칭-비대칭 매트릭스의 경우, 시공간 기억폭을 대칭 조건과 비대칭조건으로 나누어 세 집단의 비언어적 덩이짓기 능력 을 비교하고, 각 집단 별 수행도가 어떤 양상을 보이는지 확인하고 자 한다. 이와 더불어, 각 집단 내 언어능력과 언어적-비언어적 덩이 짓기 점수간에 통계적으로 유의한 상관이 있는지 보고자 한다.

구체적인 연구 질문은 다음과 같다.

1) 세 집단(단일언어 일반, 단일언어 단순언어장애, 이중언어 일 반) 간 비언어적 덩이짓기 과제(대칭-비대칭 매트릭스)의 기억 폭 증가(기억폭 3 vs. 기억폭 4 vs. 기억폭5)에 따른 자극 조건(대 칭조건 vs. 비대칭조건)의 정반응률에 유의한 차이가 있는가?

2) 세 집단(단일언어 일반, 단일언어 단순언어장애, 이중언어 일 반) 간 한국어 언어적 덩이짓기 과제(한국어 단어목록회상)의 낱말 수 증가(3낱말 vs. 5낱말 vs. 7낱말)에 따른 어순 조건(문 장어순 vs. 무선어순)의 정반응률에 유의한 차이가 있는가?

3) 이중언어 일반아동 집단 내 영어 언어적 덩이짓기 과제(영어 단어목록회상)의 낱말 수 증가(3낱말 vs. 5 낱말 vs. 7 낱말)에 따른 어순 조건(문장어순 vs. 무선어순)의 정반응률에 유의한 차이가 있는가?

4) 각 집단(단일언어 일반, 단일언어 단순언어장애, 이중언어 일 반) 내 언어능력(수용어휘력, 이야기이해 능력)과 언어적-비언 어적 덩이짓기 과제 점수 간에 유의한 상관이 있는가?

\section{연구방법}

\section{연구대상}

본 연구에서는 서울 및 경기도에 거주하는 만 4-6세 한국어 단일 언어 일반아동 22명(4;2-6;11, 남아 11명, 여아 11명), 한국어 단일언 어 단순언어장애아동 16 명(4;0-6;7, 남아 9명, 여아 7명), 한국어-영 어 이중언어 일반아동 26명(4;0-6;10, 남아 14 명, 여아 12 명), 총 64 명이참여하였다.

한국어 단일언어 일반아동 22 명의 선정기준은 다음과 같다. 1 ) 한국에서 출생하여 가정과 유치원에서 한국어를 사용하며, 2) 하 루에 영어를 학습하는 시간이 2시간을 넘지 않으며, 3) 수용·표현 어휘력 검사(Receptive \& Expressive Vocabulary Test, REVT; Kim, Hong, Kim, Jang, \& Lee, 2009)에서 수용 및 표현 어휘력이 정상범 주(-1 SD 이상)에 속하고, 4) 한국어판 카우프만 아동용 지능검사 (Korean Kaufman Assessment Battery for Children, K-ABC; Moon \& Byun, 2003)에서 비언어성 지능 표준점수가 85점 이상이며, 5) 신 체, 정서, 감각, 행동 및 기타 신경학적 문제 및 기질적인 장애를 동 
반하지 않은 아동을 대상으로 선정하였다.

한국어 단일언어 단순언어장애아동 16 명의 선정기준은 다음과 같다. 1) 한국에서 출생하여 가정과 유치원에서 한국어를 사용하 며 5점 이상이고, 2) 하루에 영어를 학습하는 시간이 2시간을 넘지 않으며, Leonard (1998)의 단순언어장애 진단기준에 따라 3) 수용. 표현 어휘력 검사 결과 수용어휘력 또는 표현어휘력이 또래집단과 비교하여 $10 \%$ ile 미만에 속하며, 4 ) 한국어판 카우프만 아동용 지능 검사에서 비언어성 지능 표준점수가 85점 이상이며, 5) 신체, 정서, 감각, 행동 및 기타 신경학적 문제 및 기질적인 장애를 동반하지 않 은 아동을 대상으로 선정하였다.

한국어-영어 이중언어 일반아동 26 명의 선정기준은 다음과 같 다. 1) 한국 및 외국에서 출생하여 모국어인 한국어(L1)를 습득하 고 그 후 영어(L2)를 습득한 순차적 이중언어아동으로, 2) 2년 이상 영어유치원 또는 국제교육기관에 재학하여 하루에 평균 5 시간 이 상 또래아동과 상호작용 및 교육프로그램에서 제 2 언어(영어)를 사 용하고(Yim, Jo, Han, \& Seong, 2016), 3) 수용· 표현 어휘력 검사 중 수용 어휘력 검사 후 오반응 문항을 영어로 시행한 합산점수와 Peabody Picture Vocabulary Test-IV (PPVT IV; Dunn \& Dunn, 2007) 검사 후 오반응 문항을 한국어로 시행한 합산점수 결과가 모 두 -1 SD 이상에 속하고, 4) 한국어판 카우프만 아동용 지능검사(K$\mathrm{ABC}$; Moon \& Byun, 2003)에서 비언어성 지능 표준점수가 85점 이 상이며, 5) 신체, 정서, 감각, 행동 및 기타 신경학적 문제 및 기질적 인 장애를 동반하지 않은 아동을 대상으로 선정하였다. 세 집단 간 생활연령 및 동작성 지능의 통제가 제대로 이루어졌는지 확인하기 위하여 일원분산분석(one-way ANOVA)을 실시한 결과, 세 집단 간 생활연령 $\left(F_{(2,63)}=.261, p>.05\right)$ 및 동작성 지능 $\left(F_{(2,63)}=1.828, p>.05\right)$ 에서는 통계적으로 유의한 차이가 나타나지 않았다. 한편, 한국어 수용 어휘력 점수는 집단 간 차이가 통계적으로 유의하였다 $\left(F_{(2,63)}=23.718, p<.001\right)$. 이에 Bonferroni를 통해 사후검정을 실시
한 결과, 단일언어 일반아동과 이중언어 일반아동의 점수가 단일언 어 단순언어장애아동의 점수에 비해 통계적으로 유의하게 높았으 며 $(p<.001)$, 단일언어 일반아동과 이중언어 일반아동 집단 간 차 이는 통계적으로 유의하지 않았다( $p>.05)$. 한국어 표현 어휘력 점 수 또한 집단 간 차이가 통계적으로 유의하였다 $\left(F_{(2,63)}=20.355\right.$, $p<.001)$. 이에 Bonferroni를 통해 사후검정을 실시한 결과, 단일언 어와 이중언어 일반아동의 점수가 단일언어 단순언어장애아동의 점수에 비해 통계적으로 유의하게 높았으며 $(p<.001)$, 단일언어와 이중언어 일반아동 집단 간 차이는 통계적으로 유의하지 않았다 ( $p>$.05). 세부적인 내용은 Table 1에 제시하였다.

\section{연구자료}

한국어 단일언어 일반아동 집단, 한국어 단일언어 단순언어장애 아동 집단, 한국어-영어 이중언어 일반아동 집단의 덩이짓기 능력 을 비교하기 위해 언어적, 비언어적 덩이짓기 과제를 실시하였다.

\section{언어적 덩이짓기 과제: 단어목록회상(Word List Recall Task)}

아동의 언어적 덩이짓기 능력을 평가하기 위해 단어목록회상 과 제를 실시하였다. 한국어 단일언어 아동의 경우 한국어로 된 단어 목록회상 과제만을 실시하였으며, 이중언어 아동은 한국어와 영어 모두로 실시하였다.

한국어 단어목록회상 과제는 Chun과 Yim (2017)의 연구과제를 사용하였다. 구체적으로 검사문항은 3 낱말 단문, 5 낱말 단문과 접 속복문, 7 낱말 접속복문으로 이루어져 있으며, 총 26문항이다. 이 는 각각 문장어순 13 문항, 무선어순 13 문항으로 구성되어 있다. 이 두 가지 어순 배열을 한 문항씩 번갈아가며 제시한다. 문장어순 배 열조건의 경우 구문구조를 이용하여 언어적 덩이짓기 전략의 접근 용이성이 높으며, 무선어순 배열조건의 경우 무선적 배열로 인해 덩 이짓기 전략의 접근 용이성이 낮다.

Table 1. Participants' characteristics

\begin{tabular}{|c|c|c|c|c|}
\hline & Mono TD (N=22) & Mono SLI (N=16) & $\mathrm{BI}$ TD (N=26) & $F$ \\
\hline Age (month) & $63.95(9.87)$ & $62.19(9.99)$ & $62.31(10.08)$ & 0.261 \\
\hline Performance $10^{\mathrm{a}}$ & $108.59(12.26)$ & $103.31(9.56)$ & 109.81 (10.63) & 1.828 \\
\hline Korean receptive vocabulary (raw score) ${ }^{b}$ & $63.95(7.81)$ & $38.75(19.40)$ & $69.73(15.46)$ & $23.718^{* * *}$ \\
\hline Korean expressive vocabulary (raw score) ${ }^{c}$ & $68.05(10.67)$ & $41.06(11.74)$ & $70.42(11.03)$ & $20.355^{* * *}$ \\
\hline English receptive vocabulary (raw score) ${ }^{d}$ & & & $85.61(20.61)$ & \\
\hline
\end{tabular}

Values are presented as mean (SDs).

Mono TD=Korean monolingual children with typical language development; Mono SLI=Korean monolingual children with specific language impairment; BI TD=KoreanEnglish bilingual children with typical language development.

${ }^{a}$ Korean Kaufman Assessment Battery for Children (K-ABC; Moon \& Byun, 2003), ${ }^{b}$ Receptive and Expressive Vocabulary Test (REVT; Kim, Hong, Kim, Jang, \& Lee, 2010), 'Receptive and Expressive Vocabulary Test (REVT; Kim et al., 2010), 'Peabody Picture Vocabulary Test-4th Ed (PPVT IV; Dunn, \& Dunn, 2007).

${ }^{* * *} p<.001$. 
Table 2. Examples of Korean word list recall (Chun \& Yim, 2017)

\begin{tabular}{|c|c|c|}
\hline Span & Sentential order & Random order \\
\hline 3 & $\begin{array}{l}{\left[\Lambda \mathrm{mma} \mathrm{tc}^{\mathrm{f}} \text { ima ib } \Lambda \mathrm{jo}\right]} \\
\text { mom, wears, skirt }\end{array}$ & $\begin{array}{l}\text { [ip } \Lambda \text { jo tc }{ }^{\text {fima }} \text { imma] } \\
\text { wears, skirt, mom }\end{array}$ \\
\hline 5 & $\begin{array}{l}\text { [^mma Sican sakwa cogim sajo] } \\
\text { mom, market, apple, some, buy }\end{array}$ & $\begin{array}{l}\text { [sajo Sican cogim sakwa } \Lambda \text { mma] } \\
\text { buy, market, some, apple, mom }\end{array}$ \\
\hline 7 & 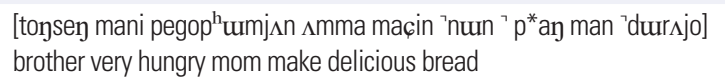 & 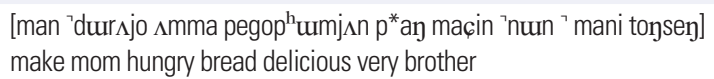 \\
\hline
\end{tabular}

Table 3. Examples of English word list recall

\begin{tabular}{lll}
\hline Span & \multicolumn{1}{c}{ Sentential order } & \multicolumn{1}{c}{ Random order } \\
\hline 3 & Boy fell hurt & Fell boy hurt \\
5 & Little baby slept all night & Baby night all little slept \\
7 & $\begin{array}{c}\text { She gave her mom some beautiful } \\
\text { flowers }\end{array}$ & $\begin{array}{l}\text { Flowers mom beautiful gave she } \\
\text { some her }\end{array}$ \\
\hline
\end{tabular}

영어 단어목록회상 과제는 한국어 단어목록회상과 동일한 패러 다임으로 제작되었다. 아동의 연령 수준에 맞는 자극문장을 선정 하기 위하여, PLS-5 (Preschool Language Sacle-5; Zimmerman, Steiner, \& Pond, 2011), CELF-4 (Clinical Evaluation of Language Fundamentals-4; Semel, Wiig, \& Secord, 2003) 및 선행연구(Boyle et al., 2013; Petruccelli et al., 2012)의 문장 따라말하기 과제에서 사 용된 문장을 일부 발췌 및 수정하여 제작하였다. 검사문항은 동일 하게 문장어순 조건 13 문항, 무선어순 조건 13 문항 총 26 문항으로 구성되어 있으며, 이 두 어순배열을 한번씩 번갈아가며 제시하였다. 과제에 사용된 단어목록 예시는 Table 2 와 Table 3 에 제시하였다. 제시 자극의 내용은 Appendix 1과같다.

비언어적 덩이짓기 과제: 대칭-비대칭 매트릭스(SymmetricAsymmetric Matrix)

아동의 비언어적 덩이짓기 능력을 평가하기 위하여 대칭-비대칭 매트릭스 과제를 실시하였다. 본 과제는 선행연구(Chun \& Yim, 2017; Hong, H. \& Yim, 2014; Gathercole \& Pickering, 2000; Huntley et al., 2011)의 컴퓨터용 공간기억폭 과제를 사용하였다. 컴퓨터 모니터에는 $4 \times 4$ 배열의 흰색 정사각형이 16 개 제시된다. 이 중 특 정 위치의 특정 정사각형이 3 개, 4 개, 5 개 순차적으로 파란색으로 점등된다. 검사자는 아동에게 순차적으로 점등되는 파란색 정사각 형의 위치를 기억한 뒤, 점등된 순서대로 컴퓨터 모니터를 가리키도 록 지시한다. 기억폭은 $3,4,5$ 로 증가되며 각각의 기억폭마다 대칭 조건 4 문항, 비대칭조건 4 문항씩 총 8 개 문항으로 구성되어있다. 자 극조건이 대칭인 경우 정사각형의 점등이 좌우대칭으로 구성되어 있으며, 대칭성을 이용하여 덩이짓기 전략의 접근 용이성이 높다.
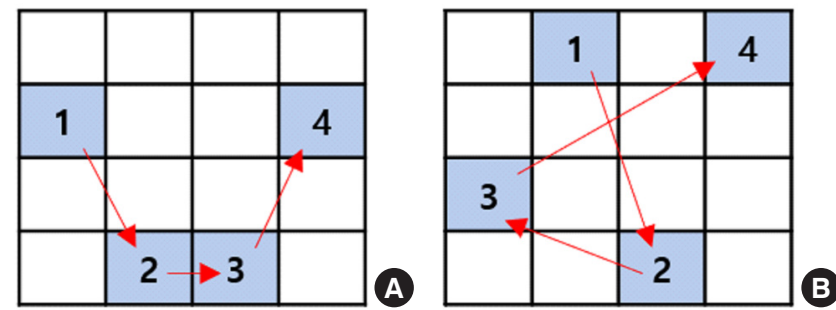

Figure 1. Examples of symmetric-asymmetric matrix task in (A) symmetric matrix task and (B) asymmetric matrix task.

반면, 비대칭조건의 경우에는 점등이 비대칭적으로 제시되기 때문 에, 비구조적 배열로 인해 덩이짓기 전략의 접근 용이성이 낮다. 자 극조건은 대칭조건과 비대칭조건이 한 번씩 번갈아가며 제시된다. 대칭-비대칭 매트릭스 과제 예시는 Figure 1에 제시하였다.

\section{이야기이해 과제}

아동의 이야기이해 능력을 평가하기 위해 페파피그 이야기이해 과제를 실시하였다. 본 과제는 이야기 책 읽기와 관련된 선행연구 (Yim et al., 2019)에서 사용된 과제를 바탕으로 제작되었으며, 언어 병리학과에 재학 중인 석사과정 3 인 및 박사과정 연구자 2인이 참 여하여 타당도를 검증하였다.

한국어 페파피그 이야기이해 과제는, 페파피그 캐릭터가 등장하 는 짧은 그림 이야기를 아동에게 보여준 뒤 이와 관련된 사실적 정 보 이해 질문, 추론적 정보 이해 질문에 답하는 과제로 각각 5점, 14 점 만점으로 구성되어 있다. 사실적 정보 이해 질문은 들려준 이야 기에서의 내용을 그대로 다시 질문하는 과제로 질문을 이해하고 이야기 내용을 기억한다면 대답할 수 있으며, 총 5 문항으로 0 점 또 는 1 점으로 채점한다. 추론적 정보 이해 질문은 들려준 이야기에 표면적으로 주어지지 않은, 표현에 함축된 정보를 아동 스스로 추 론하여 통합적으로 이해하는 능력이 필요하다. 의도추론, 감정추 론, 어휘추론 및 결과추론으로 구성되어 있으며, 총 7문항이며 0-2 점 척도로 구성되어 있다.

이중언어아동의 경우 한국어 페파피그 이야기이해 과제와 더불 어 영어 페파피그 이야기이해 과제를 제작하여 실시하였다. 영어 페 
파피그 이야기이해 과제 또한 한국어 이야기이해 과제와 동일한 패 러다임으로 진행되었으며, 각각 5점, 14 점 만점으로 구성되어 있다.

\section{자료 분석 및 결과 처리}

본 연구의 과제 수행분석을 위해 각 과제의 원점수는 모두 정반 응한 문항에 총 문항을 나누어 100 을 곱한 \%점수로 산출되었으며, SPSS ver. 21 (SPSS Inc., Chicago, IL, USA)을 사용하여 통계적 처 리를 실시하였다. 세 집단 간 대칭-비대칭 매트릭스 과제의 기억폭 증가에 따른 자극조건의 정반응률과 한국어 단어목록회상 과제의 낱말 수 증가에 따른 어순조건의 정반응률에 유의한 차이가 있는 지 알아보기 위해 삼원분산분석(three-way ANOVA)을 실시하였 다. 이중언어 일반아동 집단 내 영어 단어목록회상 과제의 낱말 수 증가에 따른 어순조건의 정반응률에 유의한 차이가 있는지 알아 보기 위해 이원분산분석(two-way ANOVA)을 실시하였다. 또한 집 단 내 언어능력(수용어휘력, 이야기이해 능력)과 언어적-비언어적 덩이짓기 과제 점수 간에 유의한 상관이 있는지 확인하기 위해 Pearson 적률상관계수(Pearson correlation coefficient)를 사용하였다.

\section{연구결과}

\section{세 집단 간 대칭-비대칭 매트릭스 비교}

세 집단에게 실시한 비언어적 덩이짓기 과제(대칭-비대칭 매트릭 스 과제)의 기억폭 증가에 따른 자극조건의 정반응률은 Figure 2 와 같다. 삼원혼합분산분석 결과 집단에 대한 주효과가 통계적으로 유의하였다 $\left(F_{(2,61)}=11.156, p<.001\right)$. 이에 Bonferroni를 사용한 사 후검정 결과 단일언어 단순언어장애아동의 정반응률 평균이 $16.72 \%$ $(\mathrm{SD}=4.22)$ 로 단일언어 일반아동 집단의 정반응률 평균 $35.23 \%$

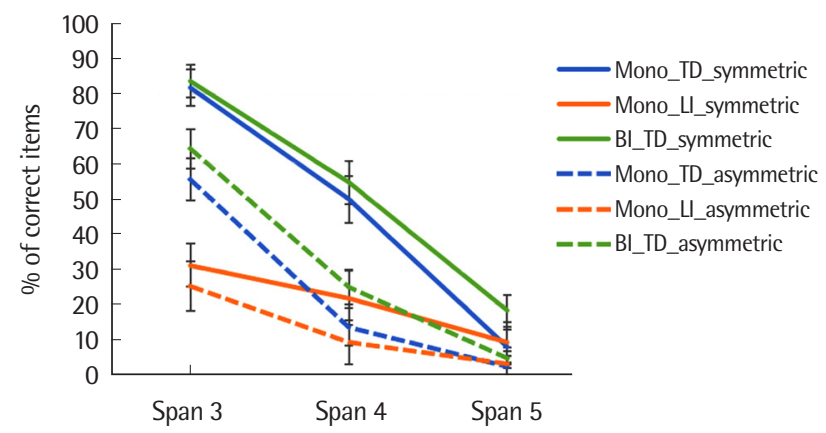

Figure 2. Symmetric-asymmetric matrix performance by group, span, and condition.

Mono TD=Korean monolingual children with typical language development; Mono SLI = Korean monolingual children with specific language impairment; $\mathrm{BI} \mathrm{TD}=$ Korean-English bilingual children with typical language development.
$(\mathrm{SD}=3.60)(p<.01)$ 와 이중언어 일반아동 집단의 정반응률 평균 $41.83 \%(\mathrm{SD}=3.31)$ 보다 통계적으로 유의하게 낮았다 $(p<.001)$. 한 편, 단일언어 일반아동 집단과 이중언어 일반아동 집단 간 차이는 통계적으로 유의하지 않았다( $p>.05)$.

집단 내 요인 중 자극조건에 대한 주효과가 통계적으로 유의하였 다 $\left(F_{(1,61)}=80.577, p<.001\right)$. 즉, 대칭조건으로 제시될 때의 평균 정 반응률이 $39.89 \%(\mathrm{SD}=2.61)$ 로, 비대칭조건으로 제시될 때의 평균 정반응률 $22.63 \%(\mathrm{SD}=2.08)$ 보다 통계적으로 유의하게 높았다.

또한 자극조건과 집단의 이차상호작용이 통계적으로 유의하였 다 $\left(F_{(2,61)}=4.884, p<.05\right)$. 이에 따른 사후검정으로 자극조건에 따 른 집단 간 차이가 있는지 알아보기 위해, 일원배치분산분석(oneway ANOVA)을 실시한 결과, 대칭조건 $\left(F_{(2,63)}=12.337, p<.001\right)$ 및 비대칭조건 $\left(F_{(2,63)}=6.673, p<.01\right)$ 에서 집단 간 차이가 통계적으로 유의하였다. 이에 Bonferroni를 이용한 사후검정 결과, 대칭조건의 경우 단일언어 단순언어장애아동은 단일언어 일반아동 $(p<.01)$ 및 이중언어 일반아동 $(p<.001)$ 과 통계적으로 유의한 차이가 있었으 며, 단일언어 일반아동과 이중언어 일반아동 간에는 통계적으로 유의한 차이가 나타나지 않았다 $(p>.05)$. 비대칭조건의 경우 단일 언어 단순언어장애아동과 이중언어 일반아동 간 통계적으로 유의 한 차이가 있었으며 $(p<.01)$ 단일언어 일반아동과 단순언어장애 $(p>.05)$ 및 단일언어 일반과 이중언어 일반 $(p>.05)$ 간에는 통계적 으로 유의한 차이가 나타나지 않았다.

기억폭에 대한 주효과가 통계적으로 유의하였다 $\left(F_{(2,122)}=191.222\right.$, $p<.001)$. 이에 Bonferroni를 이용한 사후검정 결과 기억폭이 3 개일 때의 평균 정반응률이 $57.02 \%(\mathrm{SD}=2.73)$ 로, 기억폭 4 의 평균 정반 응률 $29.12 \%(\mathrm{SD}=3.06)(p<.001)$ 및 기억폭 5의 평균 정반응률 $7.63 \%(\mathrm{SD}=1.88)$ 보다 통계적으로 유의하게 높은 점수를 보였으며 $(p<.001)$ 기억폭 4 의 정반응률 평균이 기억폭 5 에 비해 높은 점수 를 보였다 $(p<.001)$.

기억폭과 집단의 이차상호작용이 통계적으로 유의하였다 $\left(F_{(4,122)}=\right.$ $12.896, p<.001)$. 이에 따른 사후검정으로 기억폭 별로 집단 간 차 이가 있는지 알아보기 위해 일원배치분산분석(one-way ANOVA) 을 실시한 결과, 기억폭 $3\left(F_{(2,63)}=25.206, p<.001\right)$ 및 기억폭 $4\left(F_{(2,63)}=\right.$ $5.086, p<.001)$ 에서는 집단 간 차이가 통계적으로 유의하였다. Bonferroni를 이용한 사후검정 결과, 기억폭 3에서 단일언어 단순언어 장애아동은 단일언어 일반아동 $(p<.001)$ 및 이중언어 일반아동 $(p<.001)$ 과 통계적으로 유의한 차이가 있었으며, 단일언어 일반아 동과 이중언어 일반아동 간에는 통계적으로 유의한 차이가 나타나 지 않았다 $(p>.05)$. 기억폭 4 의 경우, 단일언어 단순언어장애아동 은 이중언어 일반아동 $(p<.01)$ 과 통계적으로 유의한 차이가 있었 
으며, 단일언어 일반과 이중언어 일반 $(p>.05)$ 및 단일언어 일반과 단일언어 단순언어장애( $p>.05)$ 간에는 통계적으로 유의한 차이가 나타나지 않았다 $(p>.05)$. 한편, 기억폭 5는 집단 간 차이가 통계적 으로 유의하지 않았다 $\left(F_{(2,63)}=1.279, p>.05\right)$.

또한 자극조건과 기억폭의 이차 상호작용이 통계적으로 유의하 였다 $\left(F_{(2,122)}=5.384, p<.01\right)$. 이에 따른 사후검정으로 MMATRIX SYNTAX를 사용하여 상호작용 대비검정을 실시하였다. 그 결과, 기억폭 4 에서의 자극조건 간 차이가 기억폭 5 에 비해 통계적으로 유의하게 컸다 $(p<.01)$. 하지만, 기억폭 3 및 기억폭 4 간 자극조건에 따른 차이는 통계적으로 유의하지 않았으며( $p>.05)$, 기억폭 3 및 기 억폭 5 간 자극조건에 따른 차이 또한 통계적으로 유의하지 않았다 ( $p>$.05).

한편 자극조건과 기억폭, 집단의 삼차상호작용은 통계적으로 유 의하지 않았다 $\left(F_{(4,122)}=0.972, p>.05\right)$. 세 집단의 대칭-비대칭 매트 릭스 과제의 평균 및 표준편차에 대한 기술통계는 Table 4 와 같다.

\section{세 집단 간 한국어 단어목록회상 비교}

세 집단에게 실시한 한국어 언어적 덩이짓기 과제(한국어 단어 목록회상)의 낱말 수 증가에 따른 어순조건의 정반응률은 Figure 3 과 같다. 삼원혼합분산분석 결과 집단에 대한 주효과가 통계적으 로 유의하였다 $\left(F_{(2,61)}=12.487, p<.001\right)$. 이에 Bonferroni를 사용한 사후검정 결과 단일언어 단순언어장애아동의 정반응률 평균이 $53.09 \%(\mathrm{SD}=3.40)$ 로 단일언어 일반아동 집단의 정반응률 평균 $72.62 \%(\mathrm{SD}=2.90)(p<.001)$ 와 이중언어 일반아동 집단의 정반응 률 평균 $72.74 \%(\mathrm{SD}=2.67)$ 보다 통계적으로 유의하게 낮았다 $(p<$ .001). 한편, 단일언어 일반아동 집단과 이중언어 일반아동 집단 간 차이는 통계적으로 유의하지 않았다( $p>.05)$.

집단 내 요인 중 어순조건에 대한 주효과가 통계적으로 유의하였 다 $\left(F_{(1,61)}=177.82, p<.001\right)$. 즉, 문장어순으로 제시될 때의 평균 정 반응률이 $74.00 \%(\mathrm{SD}=1.89)$ 로, 무선어순으로 제시될 때의 평균 정반응률 $58.30 \%(\mathrm{SD}=1.77)$ 보다 통계적으로 유의하게 높았다. 한
편 어순조건과 집단의 이차상호작용은 통계적으로 유의하지 않았 다 $\left(F_{(2,61)}=1.163 p>.05\right)$.

낱말 수에 대한 주효과가 통계적으로 유의하였다 $\left(F_{(2,122)}=175.39\right.$, $p<.001)$. 이에 따라 Bonferroni를 사용한 사후검정 결과 3낱말의 평균 정반응률이 $87.95 \%(\mathrm{SD}=1.50)$ 로, 5 낱말의 평균 정반응률 $61.49 \%(\mathrm{SD}=2.17)(p<.001)$ 및 7낱말의 평균 정반응률 $49.01 \%$ $(\mathrm{SD}=2.56)$ 보다 통계적으로 유의하게 높은 점수를 보였으며 $(p<$ $.001), 5$ 낱말의 정반응률 평균이 7낱말에 비해 높은 점수를 보였다 $(p<.001)$.

또한 낱말 수와 집단의 이차상호작용이 통계적으로 유의하였다 $\left(F_{(4,122)}=2.84, p<.05\right)$. 이에 따른 사후검정으로 각 낱말 수 별로 집 단 간 차이가 있는지 확인하기 위해, 일원배치분산분석(one-way $\mathrm{ANOVA})$ 을 실시한 결과, 3 낱말 $\left(F_{(2,63)}=6.575, p<.01\right), 5$ 낱말 $\left(F_{(2,63)}=\right.$ $18.219, p<.001)$ 및 7 낱말 $\left(F_{(2,63)}=5.902, p<.01\right)$ 에서 집단 간 차이 가 통계적으로 유의하였다. 이에 Bonferroni를 이용한 사후검정 결 과, 3 낱말의 경우, 단일언어 단순언어장애아동은 단일언어 일반아 동 $(p<.01)$ 및 이중언어 일반아동 $(p<.01)$ 과 통계적으로 유의한 차 이가 있었으며, 단일언어 일반아동과 이중언어 일반아동 간에는

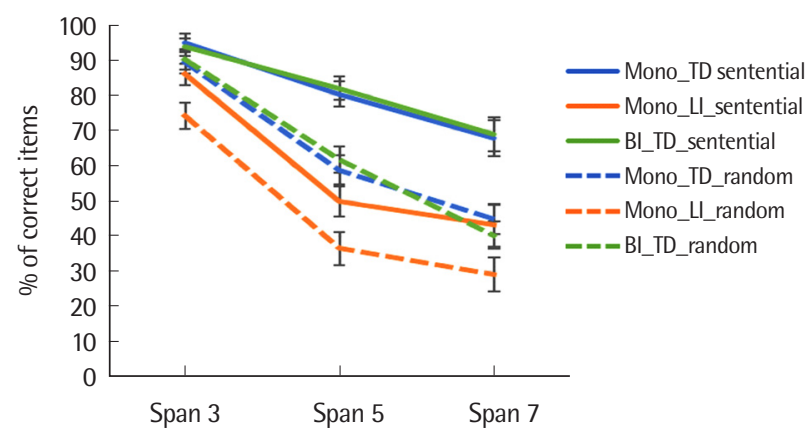

Figure 3. Korean word list recall performance by group, span, and word order. Mono TD=Korean monolingual children with typical language development; Mono SLI = Korean monolingual children with specific language impairment; $\mathrm{BI} \mathrm{TD}=$ Korean-English bilingual children with typical language development.

Table 4. Descriptive statistics of symmetric-asymmetric matrix by span and condition

\begin{tabular}{|c|c|c|c|c|c|c|}
\hline \multirow{2}{*}{ Group } & \multicolumn{3}{|c|}{ Symmetric condition } & \multicolumn{3}{|c|}{ Asymmetric condition } \\
\hline & Span 3 & Span 4 & Span 5 & Span 3 & Span 4 & Span 5 \\
\hline Mono TD (N=22) & $81.82(19.18)$ & $50.00(23.17)$ & $7.95(11.92)$ & $55.68(24.31)$ & $13.64(18.46)$ & $2.27(7.36)$ \\
\hline Mono SLI (N= 16) & $31.25(34.76)$ & $21.88(32.76)$ & $9.38(22.13)$ & 25.31 (31.38) & 9.38 (25.62) & 3.12 (12.50) \\
\hline $\mathrm{BI}$ TD (N=26) & $83.65(19.93)$ & $54.81(35.37)$ & $18.27(29.63)$ & $64.42(30.14)$ & $25.00(29.16)$ & $4.81(20.02)$ \\
\hline
\end{tabular}

Values are presented as mean (SDs).

Mono TD=Korean monolingual children with typical language development; Mono SLI=Korean monolingual children with specific language impairment; BI TD=KoreanEnglish bilingual children with typical language development. 
통계적으로 유의한 차이가 나타나지 않았다( $p>.05) .5$ 낱말의 경 우, 단순언어장애아동은 단일언어 일반아동 $(p<.001)$ 및 이중언어 일반아동 $(p<.001)$ 과 통계적으로 유의한 차이가 있었으며, 단일언 어 일반아동과 이중언어 일반아동 간에는 통계적으로 유의한 차 이가 나타나지 않았다 $(p>.05)$. 마지막으로, 7 낱말의 경우, 단순언 어장애아동은 단일언어 일반아동 $(p<.01)$ 및 이중언어 일반아동 $(p<.05)$ 과 통계적으로 유의한 차이가 있었으며, 단일언어 일반아 동과 이중언어 일반아동 간은 통계적으로 유의한 차이가 나타나지 않았다 $(p>.05)$.

또한 낱말 수와 어순조건의 이차 상호작용이 통계적으로 유의하 였다 $\left(F_{(2,122)}=17.355, p<.001\right)$. 이에 따른 사후검정으로 MMATRIX SYNTAX를 사용하여 상호작용 대비검정을 실시하였다. 그 결과, 7 낱말에서의 어순조건 간 차이가 3 낱말에 비해 통계적으로 유의하 게 컸으며 $(p<.001), 5$ 낱말에서의 어순조건 간 차이는 3 낱말에 비 해 통계적으로 유의하게 큰 것으로 나타났다 $(p<.001)$. 한편, 7 낱말 및 5 낱말 간 자극조건에 따른 차이는 통계적으로 유의하지 않았다 ( $p>$.05).

한편 어순조건과 낱말 수, 집단의 삼차상호작용이 통계적으로 유의하였다 $\left(F_{(4,122)}=3.391, p<.05\right)$. 이에 따른 사후검정으로 집단 별로 어순조건 및 낱말 수에 따른 수행력 변화를 알아보기 위해 이 원분산분석(two-way ANOVA)을 실시하였다. 그 결과, 단일언어 단순언어장애아동 집단에서는 어순조건과 낱말 수의 이차상호작 용이 통계적으로 유의하지 않았다 $\left(F_{(2,30)}=8.972, p>.05\right)$. 한편, 단 일언어 일반아동 집단에서는 어순조건 $\left(F_{(1,21)}=80.480, p<.001\right)$ 및 낱말 수에 대한 주효과가 유의하였으며 $\left(F_{(2,42)}=82.301, p<.001\right)$, 어 순조건과 낱말 수의 이차상호작용이 통계적으로 유의하였다 $\left(F_{(2,42)}=\right.$ $13.523, p<.001)$. 이중언어 일반아동 집단에서도 어순조건 $\left(F_{(1,25)}=\right.$ $85.154, p<.001)$ 과 낱말 수에 대한주효과 또한 유의하였으며 $\left(F_{(2,50)}=\right.$ $49.361, p<.001)$, 어순조건과 낱말 수의 이차상호작용이 통계적으 로 유의하였다 $\left(F_{(2,50)}=15.332, p<.001\right)$. 세 집단의 한국어 단어목 록회상 과제의 평균 및 표준편차에 대한 기술통계는 Table 5 와같다.

\section{이중언어 일반아동집단의 영어 단어목록회상}

이중언어 일반아동집단에게 실시한 영어 언어적 덩이짓기 과제 (영어 단어목록회상)의 낱말 수 증가에 따른 어순조건의 정반응률 은 Figure 4 와 같다. 이원분산분석 결과, 어순조건에 대한 주효과가 통계적으로 유의하였다 $\left(F_{(1,25)}=75.668, p<.001\right)$. 즉, 문장어순으로 제시될 때의 평균 정반응률이 $74.16 \%(\mathrm{SD}=2.67)$ 로, 무선어순으로 제시될 때의 평균 정반응률 $59.06 \%(\mathrm{SD}=2.74)$ 보다 통계적으로 유 의하게 높았다.

낱말 수에 대한 주효과가 통계적으로 유의하였다 $\left(F_{(2,50)}=201.179\right.$, $p<.001)$. 이에 따라 Bonferroni를 사용한 사후검정 결과 3 낱말의 평균 정반응률이 $97.92 \%(\mathrm{SD}=1.31)$ 로, 5 낱말의 평균 정반응률 68.21\% (SD = 3.78) $(p<.001)$ 및 7낱말의 평균 정반응률 33.71\% $(\mathrm{SD}=3.74)$ 보다 통계적으로 유의하게 높은 점수를 보였으며 $(p<$ .001), 5 낱말의 정반응률 평균이 7낱말에 비해 높은 점수를 보였다 $(p<.001)$.

또한 어순조건과 기억폭의 이차 상호작용이 통계적으로 유의하 였다 $\left(F_{(2,50)}=16.238, p<.001\right)$. 이에 따른 사후검정으로 MMATRIX SYNTAX를 사용하여 상호작용 대비검정을 실시하였다. 그 결과, 5 낱말에서의 어순조건 간 차이가 3낱말에 비해 통계적으로 유의하 게 컸으며 $(p<.001), 7$ 낱말에서의 어순조건 간차이는 3 낱말 $(p<.001)$

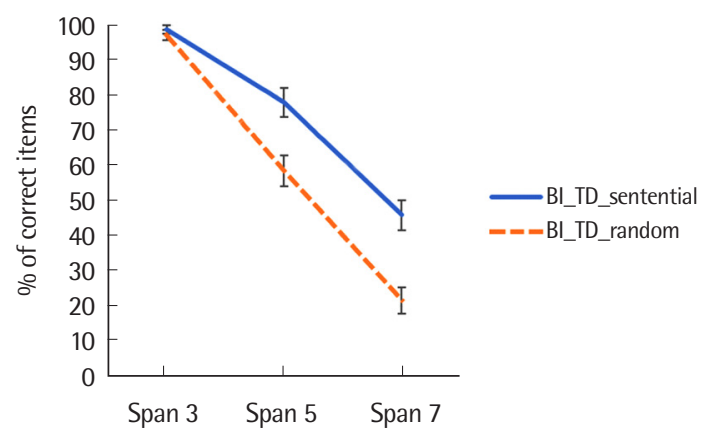

Figure 4. English word list recall performance by span, and word order. $\mathrm{BI} T \mathrm{TD}=$ Korean-English bilingual children with typical language development.

Table 5. Descriptive statistics of Korean word list recall by span and word order

\begin{tabular}{|c|c|c|c|c|c|c|}
\hline \multirow{2}{*}{ Group } & \multicolumn{3}{|c|}{ Sentential order } & \multicolumn{3}{|c|}{ Random order } \\
\hline & Span 3 & Span 5 & Span 7 & Span 3 & Span 5 & Span 7 \\
\hline Mono TD (N=22) & $94.70(8.35)$ & $80.30(15.08)$ & $67.75(17.32)$ & $89.40(11.26)$ & $58.79(15.56)$ & $44.80(16.54)$ \\
\hline Mono SLI (N=16) & 85.94 (18.94) & 49.79 (21.38) & 43.16 (22.97) & 74.02 (20.95) & $36.46(15.27)$ & $29.17(12.76)$ \\
\hline $\mathrm{BI}$ TD $(\mathrm{N}=26)$ & $93.59(9.80)$ & $81.92(15.47)$ & $68.87(29.70)$ & $90.06(12.91)$ & $61.67(23.74)$ & $40.31(24.42)$ \\
\hline
\end{tabular}

Values are presented as mean (SDs).

Mono TD=Korean monolingual children with typical language development; Mono SLI=Korean monolingual children with specific language impairment; $B \mathrm{TD}=\mathrm{Korean}$ English bilingual children with typical language development. 
및 5 낱말 $(p<.001)$ 에 비해 통계적으로 유의하게 큰 것으로 나타났 다. 세 집단의 한국어 단어목록회상 과제의 평균 및 표준편차에 대 한 기술통계는 Table 6과 같다.

\section{세 집단의 언어능력과 과제 간 상관관계}

한국어 단일언어 일반아동 집단에서 한국어 수용어휘는 이야기 이해 과제의 사실적 질문 $(r=.573, p<.01)$, 추론적 질문 $(r=.542$, $p<.01)$, 한국어 단어목록회상의 문장어순 $(r=.614, p<.01)$, 무선어 순 $(r=.455, p<.05)$ 과 높은 상관이 있는 것으로 나타났다. 이야기이 해 과제의 사실적 질문은 한국어 단어목록회상의 문장어순 $(r=.727$, $p<.01)$, 무선어순 $(r=.623, p<.01)$ 과 높은 상관이 나타났으며, 추 론적 질문은 한국어 단어목록회상의 문장어순 $(r=.510, p<.05)$, 무선어순 $(r=.468, p<.05)$, 대칭-비대칭 매트릭스의 비대칭조건 $(r=.541, p<.01)$ 과 높은 상관이 있는 것으로 나타났다. 단일언어 일반아동 집단의 언어능력과 과제 간 상관계수는 Table 7과 같다.
한국어 단일언어 단순언어장애아동 집단에서 한국어 수용어휘 는 이야기이해 과제의 사실적 질문 $(r=.714, p<.01)$, 추론적 질문 $(r=.639, p<.01)$, 대칭-비대칭 매트릭스의 대칭조건 $(r=.635, p<.01)$, 비대칭조건 $(r=.545, p<.05)$ 과 높은 상관이 나타났다. 이야기이해 과제의 사실적 질문은 한국어 단어목록회상의 무선어순 $(r=.587$, $p<.05)$ 과 매트릭스의 대칭조건 $(r=.680, p<.01)$, 비대칭조건 $(r=.604$, $p<.05)$ 과 높은 상관이 나타났으며, 추론적 질문은 한국어 단어목 록회상의 문장어순 $(r=.660, p<.01)$, 무선어순 $(r=.635, p<.01)$, 매 트릭스의 대칭조건 $(r=.608, p<.05)$, 비대칭조건 $(r=.627, p<.01)$ 과 상관이 높은 것으로 나타났다. 단일언어 단순언어장애아동 집단의 언어능력과 과제 간 상관계수는 Table 8과 같다.

한국어-영어 이중언어 일반아동 집단에서 한국어 수용어휘는 영어 수용어휘 $(r=.734, p<.01)$, 한국어 이야기이해 과제의 사실적 질문 $(r=.446, p<.05)$, 영어 이야기이해 과제의 추론적 질문 $(r=.525$, $p<.01)$, 한국어 단어목록회상의 무선어순 $(r=.432, p<.05)$, 영어

Table 6. Descriptive statistics of English word list recall by span and word order

\begin{tabular}{|c|c|c|c|c|c|c|}
\hline \multirow{2}{*}{ Group } & \multicolumn{3}{|c|}{ Sentential order } & \multicolumn{3}{|c|}{ Random order } \\
\hline & Span 3 & Span 5 & Span 7 & Span 3 & Span 5 & Span 7 \\
\hline $\mathrm{BI}$ TD (N=26) & 98.71 (6.54) & 77.95 (20.94) & 45.81 (22.00) & $97.12(7.43)$ & 58.46 (23.04) & 21.61 (18.77) \\
\hline
\end{tabular}

Values are presented as mean (SDs).

$\mathrm{BI} \mathrm{TD}=$ Korean-English bilingual children with typical language development.

Table 7. The correlation coefficients among tasks in monolingual children with typical language development

\begin{tabular}{lccccc}
\hline & Receptive vocabulary $^{\mathrm{a}}$ & Story_Literal $^{\mathrm{b}}$ & Story_Inference $^{\mathrm{c}}$ & Sentential recall $^{*}$ & Random recall $^{\text {Symmetric matrix }}$ \\
\hline Story_Literal $^{\mathrm{b}}$ & $.573^{* *}$ & & & & \\
Story_Inference $^{\mathrm{c}}$ & $.542^{* *}$ & $.574^{* *}$ & & & \\
Sentential recall & $.614^{* *}$ & $.727^{* *}$ & $.510^{*}$ & $.737^{* *}$ & .148 \\
Random recall & $.455^{*}$ & $.623^{* *}$ & $.468^{*}$ & .021 & .066 \\
Symmetric matrix & .007 & .183 & .041 & .061 & .263 \\
Asymmetric matrix & .188 & .222 & $.541^{* *}$ & \\
\hline
\end{tabular}

${ }^{a}$ Receptive and Expressive Vocabulary Test (REVT; Kim et al., 2009), ' Story comprehension task: Literal information task, 'Story comprehension task: Inference task. ${ }^{*} p<.05,{ }^{* *} p<.01$.

Table 8. The correlation coefficients among tasks in monolingual children with specific language impairment

\begin{tabular}{lccccc}
\hline & Receptive vocabulary $^{\mathrm{a}}$ & Story_Literal $^{\mathrm{b}}$ & Story_Inference $^{\mathrm{c}}$ & Sentential recall & Random recall $^{\text {Symmetric matrix }}$ \\
\hline Story_Literal $^{\mathrm{b}}$ & $.714^{* *}$ & & & & \\
Story_Inference $^{\mathrm{c}}$ & $.639^{* *}$ & $.810^{* *}$ & & & \\
Sentential recall & .384 & .462 & $.660^{* *}$ & & \\
Random recall & .374 & $.587^{*}$ & $.635^{* *}$ & $.817^{* *}$ & $.518^{*}$ \\
Symmetric matrix & $.635^{* *}$ & $.680^{* *}$ & $.608^{*}$ & $.589^{*}$ & $.527^{*}$ \\
Asymmetric matrix & $.545^{*}$ & $.604^{*}$ & $.627^{* *}$ & $.582^{* *}$ \\
\hline
\end{tabular}

${ }^{a}$ Receptive and Expressive Vocabulary Test (REVT; Kim et al., 2009), 'bStory comprehension task: Literal information task, '`Story comprehension task: Inference task. ${ }^{*} p<.05,{ }^{* *} p<.01$. 
Table 9. The correlation coefficients among tasks in monolingual children with specific language impairment

\begin{tabular}{|c|c|c|c|c|c|c|c|c|c|c|c|}
\hline & $\mathrm{REVT}^{\mathrm{a}}$ & $\mathrm{PPVT}^{\mathrm{b}}$ & Literal $^{\mathrm{K}}$ & $\underset{\text { Infer }^{\mathrm{d}}}{\text { K_Story_ }}$ & Literal $^{\text {E_Story_- }}$ & $\underset{\text { Infer }^{f}}{\text { E_Story_ }}$ & $\begin{array}{l}\text { K_senten- } \\
\text { tial recall }\end{array}$ & $\underset{\text { recall }}{\text { K_Random }}$ & $\begin{array}{l}\text { E_senten- } \\
\text { tial recall }\end{array}$ & $\begin{array}{c}\text { E_random } \\
\text { recall }\end{array}$ & $\begin{array}{c}\text { Symmetric } \\
\text { matrix }\end{array}$ \\
\hline $\mathrm{PPVT}^{\mathrm{b}}$ & $.734^{* *}$ & & & & & & & & & & \\
\hline K_Story_Literal ${ }^{c}$ & $.446^{*}$ & $.450^{*}$ & & & & & & & & & \\
\hline K_Story_Infer ${ }^{d}$ & .307 & $.406^{*}$ & .216 & & & & & & & & \\
\hline E_Story_Literal ${ }^{e}$ & .083 & .179 & .268 & .094 & & & & & & & \\
\hline E_Story_Infer ${ }^{\dagger}$ & $.525^{* *}$ & .286 & .353 & $.477^{*}$ & .001 & & & & & & \\
\hline K_sentential recall & .372 & .179 & .057 & .136 & .164 & -.034 & & & & & \\
\hline K_random recall & $.432^{*}$ & .258 & .012 & .248 & .095 & .028 & $.854^{* *}$ & & & & \\
\hline E_Sentential recall & $.485^{*}$ & $.542^{* *}$ & .193 & .368 & $.389^{*}$ & -.036 & $.388^{*}$ & $.497^{* *}$ & & & \\
\hline E_random recall & $.547^{* *}$ & .364 & .023 & .234 & .286 & .077 & $.602^{* *}$ & $.750^{* *}$ & $.750^{* *}$ & & \\
\hline Symmetric matrix & $.689^{* *}$ & $.681^{* *}$ & .189 & $.408^{*}$ & .314 & .142 & .285 & .351 & $.505^{* *}$ & $.469^{*}$ & \\
\hline Asymmetric matrix & $.438 *$ & $.588^{* *}$ & .243 & $.423^{*}$ & .195 & -.091 & .159 & .169 & $.523^{* *}$ & .294 & $.642^{* *}$ \\
\hline
\end{tabular}

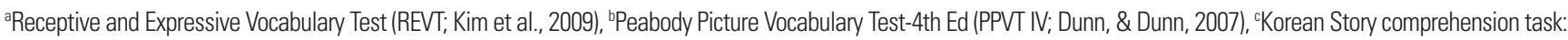
Literal information task, ${ }^{~}$ Korean Story comprehension task: Inference task, ${ }^{\circledR}$ English Story comprehension task: Literal information task, ${ }^{\mathrm{f} E n g l i s h}$ Story comprehension task: Inference task.

${ }^{*} p<.05,{ }^{* *} p<.01$.

단어목록회상의 문장어순 $(r=.485, p<.05)$ 과 무선어순 $(r=.547$, $p<.01)$, 대칭-비대칭 매트릭스의 대칭조건 $(r=.689, p<.01)$, 비대칭 조건 $(r=.438, p<.05)$ 과 상관이 높은 것으로 나타났다. 영어 수용 어휘는 한국어 이야기이해 과제의 사실적 질문 $(r=.450, p<.05)$ 과 추론적 질문 $(r=.406, p<.05)$, 영어 단어목록회상의 무선어순 $(r=$ $.542, p<.01)$, 그리고 대칭-비대칭 매트릭스의 대칭조건 $(r=.681$, $p<.01)$, 비대칭조건 $(r=.588, p<.01)$ 과상관이 높은 것으로 나타났다. 한국어 이야기이해 과제의 사실적 질문과 통계적으로 유의한 상 관을 보인 과제는 없었다. 추론적 질문은 영어 이야기이해 과제의 추론적 질문 $(r=.477, p<.05)$ 과 대칭-비대칭 매트릭스의 대칭조건 $(r=.408, p<.05)$, 비대칭조건 $(r=.423, p<.05)$ 과 높은 상관이 나타 났다. 한편, 영어 이야기이해 과제의 사실적 질문은 영어 단어목록 회상의 문장어순 $(r=.389, p<.05)$ 과 높은 상관이었으며, 추론적 질 문과 통계적으로 유의한 상관을 보인 과제는 없었다. 이중언어 일 반아동집단의 언어능력과 과제 간 상관계수는 Table 9 와 같다.

\section{논의 및 결론}

본 연구에서는 한국어-영어 이중언어 일반아동과 한국어 단일 언어 일반아동 및 단순언어장애아동의 일화적 완충기의 덩이짓기 능력을 비교하고자 하였다. 이에 본 연구는 일화적 완충기를 측정 하는 과제로 언어적, 비언어적 덩이짓기 과제를 사용하였다. 언어적 덩이짓기 과제의 경우 어순조건을 문장어순과 무선어순으로 구분 하였으며, 비언어적 덩이짓기 과제의 경우 시공간 기억폭을 대칭조 건과 비대칭조건으로 구분해 덩이짓기 능력의 효율성을 비교하고
자 하였다.

연구결과, 대칭-비대칭 매트릭스 과제에서 단일언어 단순언어장 애아동 집단은 단일언어 및 이중언어 일반아동 집단과 비교해 유 의하게 더 낮은 수행력을 보였다. 이는 단순언어장애아동의 작업기 억의 결함이 시공간 영역에서도 나타나며, 언어적 특성 및 언어 발 달에도 영향을 미칠 수 있다고 보고된 선행연구(Lisa \& Gathercole, 2006; Montgomery, 1993; Poppen et al., 1969)를 지지해주는 결과 이다. 국내의 선행연구에서도 단순언어장애아동은 또래 일반아동 과 비교해 시각 작업기억 과제에서 더 낮은 수행을 보인다고 보고되 었다(Yim, Yang, \& Kim, 2015; Hong, H. \& Yim, 2014). 이에 단순 언어장애아동 집단은 언어적인 영역뿐만 아니라 비언어적인 영역 에서도 덩이짓기 능력과 그 효율성이 결여된 것으로 해석할 수 있 다. 즉, 단순언어장애아동 집단의 덩이짓기 능력과 작업기억의 결 함이 구어청각적인 측면뿐만 아니라 비언어적 측면에서도 나타나 는 일반적인 결함인 것으로 해석된다.

한편, 이중언어 유무와 상관없이 두 일반아동 집단 간의 수행력 에는 통계적으로 유의한 차이가 나타나지 않았는데, 이는 일반아 동의 비언어적 덩이짓기 능력이 이중언어 사용유무에 영향을 받지 않는 것으로 볼 수 있다. 이는 Kohnert와 Windsor (2004)의 선행연 구에서 영어 단일언어와 스페인어-영어 이중언어 일반아동 집단이 영어 단일언어 단순언어장애 집단과 비교해 더 높은 비언어적 시각 적 과제 수행력을 보인 결과와도 일치한다. 즉, 이중언어 사용유무 에 상관없이 정상발달아동은 단순언어장애아동과 비교해 비언어 적 정보 처리 능력에 있어 더 높은 효율성을 보이는 것으로 해석할 수 있다. 
자극조건의 경우 대칭조건의 평균 정반응률이 비대칭으로 제시 될 때의 평균보다 통계적으로 유의하게 높은 것으로 나타났다. 이 는 시공간 기억폭을 다룬 선행연구의 결과들과 일치한다(Allen et al., 2006; Baddeley et al., 2011; Huntley et al., 2011). 시공간 기억폭 과제에서 자극조건이 대칭으로 제시될 때, 대칭성을 이용하여 덩이 짓기 전략을 활용하기에 더 용이하며, 비대칭조건은 비구조적인 배 열로 인하여 덩이짓기 전략의 접근 용이성이 낮다고 볼 수 있다. 즉 대칭조건이 일화적 완충기를 이용한 인지적 이익이 비대칭조건에 비해 더 큰 것을 의미한다.

또한 자극조건과 집단의 상호작용이 통계적으로 유의하였는데, 특히 대칭조건에서 단순언어장애아동 집단은 두 일반아동 집단과 비교하여 유의하게 낮은 수행력을 보였다. 이는 덩이짓기 전략을 사용하기 더 용이한 대칭성 조건에서도 단순언어장애아동은 일반 아동 집단과 비교해 그 효율성이 낮은 것으로 해석할 수 있다. 기억 폭과 집단의 상호작용 또한 통계적으로 유의하였는데, 특히 기억폭 3 에서 단순언어장애아동 집단이 두 일반아동 집단과 비교하여 통 계적으로 유의하게 낮은 수행력을 보인 것은 이들의 낮은 시공간적 인 기억 용량의 영향이 있는 것으로 해석된다.

한편 자극조건, 기억폭, 그리고 집단 간의 삼차 상호작용은 나타 나지 않았다. 이에 비언어적 덩이짓기를 측정하는 방법으로 대칭비대칭 매트릭스 과제 외에도 다른 인지전략을 활용할 수 있는 과 제를 추가적으로 실시하는 것을 고려해 볼 수 있다. 또한 일화적 완 충기를 측정하는 선행연구에서 비언어적 덩이짓기 능력을 측정한 연구는 언어적 덩이짓기 능력과 비교하였을 때 상대적으로 그 수가 적기 때문에, 단순언어장애아동 집단과 일반아동 집단 간 차이가 일반적인지 추가적으로 연구할 필요가 있다.

한국어 단어목록회상 과제에서 또한 단순언어장애아동 집단은 두 일반아동 집단과 비교해 통계적으로 유의하게 더 낮은 수행력 을 보였다. 이는 단순언어장애아동과 일반아동을 대상으로 실시한 문장 따라말하기 과제 및 일화적 완충기를 연구한 기존연구의 결 과들과 일치한다(Becker \& McGregor, 2016; Boyle et al., 2013; Gathercole, Pickering, Ambridge, \& Wearing, 2004). Petruccelli et al. (2012)에 따르면 단순언어장애아동은 일반아동과 비교하여 작업 기억과 장기기억, 그리고 언어 처리시스템을 통합하는 일화적 완충 기 능력이 더 낮다고 보고되었다. 즉, 단순언어장애아동 집단은 앞 선 비언어적 덩이짓기 능력 결함과 더불어 언어적 덩이짓기 능력에 서도 그 효율성이 결여되었다고 볼수 있다.

한편, 언어적 덩이짓기 과제에서도 이중언어 유무와 상관없이 두 일반아동 집단 간 수행력에는 통계적으로 유의한 차이가 나타나지 않았다. 즉, 일반아동의 언어적 덩이짓기 능력 또한 이중언어 사용
유무에 영향을 받지 않는 것으로 볼 수 있다. 이는 기존 단일언어와 이중언어 아동을 대상으로 실시한 문장 따라말하기 선행연구 결 과와 일치한다(Gutié.rrez-Clellen et al., 2006; Ziethe et al., 2013). 선행연구에 따르면, 표준화된 언어검사에서 정상발달을 보이는 이 중언어 일반아동이 한 언어로만 어휘를 검사할 경우, 단일언어 단 순언어장애아동과 수행도가 부분적으로 겹칠 가능성이 보고된 반 면, 본 연구의 덩이짓기 과제 수행도에서는 이중언어 일반아동의 수행이 단일언어 단순언어장애아동에 비해 유의하게 높았다. 이는 언어적, 비언어적 덩이짓기 과제가 단순히 표면의 어휘능력이 아닌, 언어 기저의 처리과정을 반영하는 검사인 것으로 해석할 수 있다.

한편, Meir, Walters, \& Armon-Lotem (2016) 연구의 러시아어 단일언어와 러시아-히브리어 이중언어 아동을 대상으로 실시한 L1 문장 따라말하기 과제에서 이중언어 일반아동 집단이 더 낮은 L1 러시아어 문장따라말하기 과제 수행력을 보인 결과와는 반대의 결 과이다. 이는 본 연구에 참여한 한국어-영어 이중언어아동 집단의 $\mathrm{REVT}$ 수용어휘력 점수는 한국어 단일언어 일반아동 집단과 통계 적으로 유의한 차이가 나지 않았던 반면( $p>$.05), Meir et al. (2016) 연구에서는 두 집단의 러시아어 원점수가 통계적으로 유의한 차이 가 있었던 것 $(p<.01)$ 으로 유추해 볼 수 있다.

자극조건의 경우 문장어순의 평균 정반응률이 무선조건의 평균 정반응률보다 통계적으로 유의하게 높은 것으로 나타났다. 이는 Baddley et al. (2009)의 연구에서 실시한 문장폭 기억과제의 문장 순 배열이 무선 순 배열과 비교하여 덩이짓기를 통해 단기기억 용 량에서 이익을 얻은 결과와 상통한다. 또한 Chun과 Yim (2017)의 한국어 단어목록회상 과제에서도 어순조건이 문장 순 일 때 무선 순 배열과 비교하여 더 높은 수행력을 보였다. 즉 아동에게 익숙한 문장어순을 회상할 때, 장기기억과의 상호작용으로 형성되는 덩이 짓기가 더 용이하며, 일화적 완충기를 이용한 인지적 이익 또한 무 선어순과 비교해 더 큰 것으로 해석된다.

또한 기억폭의 경우, 낱말 수가 증가할수록 세 집단 모두 수행력 은 낮아졌다. 즉, 비언어적 덩이짓기 과제와 마찬가지로 언어적 덩이 짓기 과제에서도 기억폭이 덩이짓기와상관이 있음을 보여준다. 이 는 문장 따라말하기 과제에서 어절 수가 증가할수록 낮은 회상률 을 보인 Ahn과 Kim (2000)의 연구와 단어목록회상 과제에서 기억 폭이 증가할수록 수행력이 낮아진 Chun과 Yim (2017)의 연구결 과를 지지해주는 결과이다.

기억폭인 낱말 수와 집단의 상호작용은 통계적으로 유의하였는 데, 3 낱말, 5 낱말과 7 낱말 모두에서 집단 간 통계적으로 유의한 차 이가 나타났다. 모든 낱말 수에서 단순언어장애아동 집단은 단일 언어 및 이중언어 일반아동 집단과 비교하여 통계적으로 유의하게 
낮은 수행력을 보였는데, 이는 단순언어장애집단의 낮은 언어적 덩 이짓기 능력의 영향이 있는 것으로 해석된다. 또한 기억폭이 3낱말, 5낱말, 7낱말인 경우 모두 단일언어 일반아동과 이중언어 일반아 동 집단 간 통계적으로 유의한 차이가 나타나지 않았다. 이를 바탕 으로 기억폭 증가에 따른 언어적 덩이짓기 수행력, 즉 일화적 완충 기의 효율적 기능은 언어 기저의 능력과 상관이 있기 때문에 이중 언어 사용유무의 영향을 받지 않는 것으로 해석된다.

이중언어 일반아동 집단이 L1인 한국어 단어목록회상에서 보인 양상이 L2를 사용한 영어 덩이짓기 과제에서도 동일하게 나타나는 지 확인하기 위하여 영어 단어목록회상을 실시하였다. 그 결과, 영 어 단어목록회상에서도 마찬가지로 문장어순이 무선조건의 평균 정반응률보다 통계적으로 유의하게 더 높아 선행연구 결과와 일치 하는 것으로 나타났다(Baddley et al., 2009). 이는 이중언어 아동이 사용하는 두 언어 모두에서 어순조건이 문장 순일 때 덩이짓기를 통한 단기기억 용량의 이익을 얻는 것으로 해석된다. 즉, $\mathrm{L} 2$ 인 영어 를 사용한 언어적 덩이짓기 과제에서도 문장어순이 무선어순과 비 교해 일화적 완충기를 이용한 인지적 이익이 더 큰 것으로 보인다. 기억폭 또한 한국어 단어목록회상과 동일하게 낱말 수가 증가할수 록 수행력은 낮아졌다. 즉, 비언어적 덩이짓기 과제와 마찬가지로 $\mathrm{L} 2$ 를 사용한 언어적 덩이짓기 과제에서도 기억폭과 덩이짓기와상 관이 있음을 보여준다.

한국어 단일언어 일반아동 집단은 수용어휘력과 사실적, 추론 적 정보 이해력 모두에서 단어목록회상의 문장어순과 무선어순과 통계적으로 유의한 상관관계를 보였다. 이는 단어목록회상 과제에 관여하는 언어능력의 기저 기제가 서로 밀접한 관련이 있을 가능 성을 보여준다. 한편, 대칭-비대칭 매트릭스 과제의 대칭조건과는 아동의 언어능력이 모두 상관을 보이지 않았으며, 추론적 정보 이 해력만이 비대칭조건과 상관을 보였다. 이는 언어적 덩이짓기 과제 에 수반되는 구어청각적 양상과 언어능력의 연관성에 비해, 비언어 적 덩이짓기 과제에서는 그 연관성이 낮음을 보여준다.

반면 단일언어 단순언어장애아동 집단은 수용어휘력과 사실적, 추론적 정보 이해력 모두에서 대칭-비대칭 매트릭스의 대칭조건, 비대칭조건과 통계적으로 유의한 상관을 보였다. 수용어휘력의 경 우 단어목록회상의 두 어순조건과는 통계적으로 유의한 상관을 보이지 않았다. 이는 단순언어장애아동의 어휘력과 대칭-비대칭 조 건이 통계적으로 유의한 상관을 보이고 두 어순조건과는 통계적으 로 유의한 상관이 나타나지 않은 Chun과 Yim (2017)의 연구결과 와 일치한다. 한편, 사실적 정보 이해력의 경우 무선어순과 통계적 으로 유의한 상관이 나타났으며 추론적 정보 이해력은 무선어순과 문장어순 모두 통계적으로 유의한 상관을 보였다. 이는 단순언어
장애아동의 수용어휘력은 비언어적 덩이짓기 능력과 연관성이 높 으며, 이야기이해력은 언어적 덩이짓기 능력과 그 연관성이 높음을 보여준다.

마지막으로 이중언어 일반아동 집단의 경우 한국어 수용어휘력 은 한국어 무선어순, 영어 문장어순과 무선어순, 대칭조건과 비대 칭조건에서 통계적으로 유의한 상관을 보였으며, 영어 수용어휘력 은 영어 문장어순, 대칭조건과 비대칭조건에서 통계적으로 유의한 상관이 나타났다. 한편, 한국어 사실적 정보 이해력과 영어 추론적 정보 이해력은 덩이짓기 과제의 자극조건과 상관이 나타나지 않았 다. 이러한 양상은 단일언어 일반아동 집단과 비교하여, 아동의 언 어능력과 언어적 덩이짓기 능력, 즉 일화적 완충기의 연관성이 상대 적으로 낮음을 보여준다. 이에, 이중언어아동은 단일언어아동과 비교해 일화적 완충기와 덩이짓기 능력의 효율성을 설명하는 데 있 어, 수용어휘력과 이야기이해력 외에도 그 기저에 추가적인 요인이 있음을 예측해 볼수 있다.

향후 연구에서는 한국어-영어 이중언어 단순언어장애아동 집단 을 포함한다면, 한국어 단어목록회상뿐만 아니라 영어 단어목록 회상이 이중언어아동의 단순언어장애 유무를 판별하는 데 유용한 지 확인할 수 있을 것이다. 또한 덩이짓기 능력을 측정하는 본 과제 가 단순언어장애 유무를 판별하는 데 유용한지를 더욱 심층적으 로 분석하기 위해서는 각 단어목록회상 과제에 나타난 오류패턴을 분석하는 후속 연구를 진행해 볼 필요가 있다. 선행연구에 따르면, 이중언어 일반아동과 단일언어 일반아동의 오류 패턴은 비슷한 양 상을 보였으며(Komeili \& Marshall, 2013) 이중언어 단순언어장애 아동의 경우 오류의 양과 패턴 또한 일반아동과 차이가 나타났다 고 보고되었다(Meir et al., 2016). 따라서 이러한 선행연구들의 결 과를 기반으로 집단 간 수행력 비교와 더불어 오류 패턴을 함께 분 석하여 비교한다면, 아동 언어발달 기저의 능력을 평가하는 데 있 어 유용한 기초자료로 활용될 수 있을 것이다.

\section{REFERENCES}

Ahn, J. S., \& Kim, Y. T. (2000). The effect of syntactic complexity on sentence repetition performance and intelligibility between specific language impairment and normal children. Korean Journal of Speech Science, 7(3), 249262.

Allen, R. J., Baddeley, A. D., \& Hitch, G. J. (2006). Is the binding of visual features in working memory resource-demanding? Journal of Experimental Psychology: General, 135(2), 298-313.

Alloway, T. P., Gathercole, S. E., Willis, C., \& Adams, A. M. (2004). A struc- 
tural analysis of working memory and related cognitive skills in young children. Journal of Experimental Child Psychology, 87(2), 85-106.

Baddeley, A. D., Allen, R., \& Hitch, G. (2009). Working memory and binding in sentence recall. Journal of Memory and Language, 61(3), 438-456.

Baddeley, A. D. (2000). The episodic buffer: a new component of working memory. Trends in Cognitive Science, 4(11), 417-423.

Baddeley, A. D., \& Hitch, G. J. (1974). Working memory. In G. A. Bower (Ed.), Recent advances in learning and motivation (pp. 47-90). New York, NY: Academic Press.

Baddeley, A. D., Allen, R. J., \& Hitch, G. J. (2011). Binding in visual working memory: the role of the episodic buffer. Neuropsychologia, 49(6), 13931400 .

Becker, T., \& McGregor, K. (2016). Learning by listening to lectures is a challenge for college students with developmental language impairment. Journal of Communication Disorders, 64, 32-44.

Bialystok, E., Luk, G., Peets, K. F., \& Yang, S. (2010). Receptive vocabulary differences in monolingual and bilingual children. Bilingualism: Language and Cognition, 13(4), 525-531.

Boerma, T., Wijnen, F., Leseman, P., \& Blom, E. (2017). Grammatical morphology in monolingual and bilingual children with and without language impairment: the case of Dutch plurals and past participles. Journal of Speech, Language, and Hearing Research, 60(7), 2064-2080.

Boyle, W., Lindell, A. K., \& Kidd, E. (2013). Investigating the role of verbal working memory in young children's sentence comprehension. Language Learning, 63(2), 211-242.

Campbell, T., Dollaghan, C., Needleman, H., \& Janosky, J. (1997). Reducing bias in language assessment: processing dependent measures. Journal of Speech, Language, and Hearing Research, 40(3), 519-525.

Chun, S. Y., \& Yim, D. S. (2017). A comparative study of chunking mechanism in children with and without language delay. Communication Sciences and Disorders, 22(2), 233-244.

Cowan, N. (2001). The magical number 4 in short-term memory: A reconsideration of mental storage capacity. Behavioral and Brain Sciences, 24(1), $87-114$.

Dollaghan, C., \& Campbell, T. F. (1998). Nonword repetition and child language impairment. Journal of Speech, Language, and Hearing Research, 41(5), 1136-1146

Dunn, L. M., \& Dunn, D. M. (2007). Peabody Picture Vocabulary Test fourth edition. Bloomington, MN: NCS Pearson, Inc.

Gathercole, S. E., \& Pickering, S. J. (2000). Assessment of working memory in six-and seven-year-old children. Journal of Educational Psychology, 92(2), 377-390.

Gathercole, S., Pickering, S., Ambridge, B., \& Wearing, H. (2004). The Structure of working memory from 4 to 15 years of age. Developmental Psychology, 40(2), 177-190.

Gutié.rrez-Clellen, V. F., Restrepo, A. M., \& Simó.n-Cereijido, G. (2006). Evaluating the discriminant accuracy of a grammatical measure with Spanishspeaking children. Journal of Speech, Language, and Hearing Research, 49(6), 1209-1223.

Hakansson, G., \& Nettelbladt, U. (1996). Similarities between SLI and L2 children: evidence from the acquisition of Swedish word order. In C. E. Johnson \& J. H. V. Gilbert (Eds.), Children's language (pp. 135-151). Mahwah, NJ: Lawrence Erlbaum.

Hong, H., \& Yim, D. (2014). Working memory subsystems and receptive vocabulary in children with specific language impairment. Journal of Speech \& Hearing Disorders, 23(2), 35-44.

Hong, S., \& Yim, D. (2014). The assessment of language impairment in bilingual children through learning and memory tasks. Communication Sciences \& Disorders, 19(1), 31-44.

Huntley, J., Bor, D., Hampshire, A., Owen, A., \& Howard, R. (2011). Working memory task performance and chunking in early Alzheimer's disease. The British Journal of Psychiatry, 198(5), 398-403.

Kan, P. F., \& Kohnert, K. (2005). Preschoolers learning Hmong and English: lexical-semantic skills in L1 and L2. Journal of Speech, Language, and Hearing Research, 48(2), 372-383.

Kim, Y. T., Hong, G. H., Kim, K. H., Jang, H. S., \& Lee, J. Y. (2009). Receptive \& expressive vocabulary test (REVT). Seoul: Seoul Community Rehabilitation Center.

Kohnert, K., \& Windsor, J. (2004). The search for common ground: part II. Nonlinguistic performance by linguistically diverse learners. Journal of Speech, Language, and Hearing Research, 47(4), 891-903.

Kohnert, K., Windsor, J., \& Yim, D. (2006). Do language-based processing tasks separate children with language impairment from typical bilinguals? Learning Disabilities Research \& Practice, 21(1), 19-29.

Kohnert, K. (2008). Language disorders in bilingual children and adults. San Diego, CA: Plural.

Kohnert, K. (2010). Bilingual children with primary language impairment: issues, evidence and implications for clinical actions. Journal of Communication Disorders, 43(6), 456-473.

Komeili, M., \& Marshall, C. (2013). Sentence repetition as a measure of mor- 
phosyntax in monolingual and bilingual children. Clinical Linguistics and Phonetics, 27(2), 152-62.

Laws, G., \& Bishop, D. (2003). A comparison of language abilities is adolescents with Down syndrome and children with specific language impairment. Journal of Speech, Language, and Hearing Research, 46(6), 1324-1329.

Leonard, L. B. (1998). Children with specific language impairment. Cambridge, MA: MIT Press.

Leseman, P. M. (2000). Bilingual vocabulary development of Turkish preschoolers in the Netherlands. Journal of Multilingual and Multicultural Development, 21(2), 93-112.

Lisa, M., \& Gathercole, S. (2006). Short-term and working memory in specific language impairment. International Journal of Language and Communication Disorders, 41(6), 675-693.

Meir, N., Walter, J., \& Armon-Lotem, S. (2016). Disentangling SLI and bilingualism using sentence repetition tasks: the impact of L1 and L2 properties. International Journal of Bilingualism, 20(4), 421-452.

Miller, G. A. (1956). The magical number seven, plus or minus two: some limits on our capacity for processing information. Psychological review, 101(2), 343-352.

Montgomery, J., Evans, J., Fargo, J., Schwartz, S., \& Gillam, R. (2018). Structural relationship between cognitive processing and syntactic sentence comprehension in children with and without developmental language disorder. Journal of Speech, Language, and Hearing Research, 61(12), 2950 $-2976$.

Montgomery, J. (1993). Haptic recognition of children with specific language impairment: effects of response modality. Journal of Speech, Language, and Hearing Research, 36(1), 98-104.

Moon, S. B., \& Byun, C. J. (2003). Korean Kaufman Assessment Battery for Children (K-ABC). Seoul: Hakjisa.

Nobre, A. D. P., Rodrigues, J. D. C., Sbicigo, J. B., Piccolo, L. D. R., Zortea, M., Junior, S. D., \& de Salles, J. F. (2013). Tasks for assessment of the episodic buffer: a systematic review. Psychology \& Neuroscience, 6(3), 331-343.
Paradis, J., Crago, M., Genesee, F., \& Rice, M. (2003). French-English bilingual children with SLI: how do they compare with their monolingual peers? Journal of Speech, Language, and Hearing Research, 46(2), 113-127.

Petruccelli, N., Bavin, E., \& Bretherton, L. (2012). Children with specific language impairment and resolved late talkers: working memory profiles at 5 years. Journal of Speech, Language, and Hearing Research, 55(6), 1690-1703.

Poppen, R., Stark, J., Eisenson, J., Forrest, T., \& Wertheim, G. (1969). Visual sequencing performance of aphasic children. Journal of Speech, Language, and Hearing Research, 12(2), 288-300.

Semel, E., Wiig, E., \& Secord, W. (2003). Clinical evaluation of language fundamentals-4th edition. San Antonio, TX: The Psychological Corporation.

Welsh, M. C., \& Pennington, B. F. (1988). Assessing frontal lobe functioning in children: Views from developmental psychology. Developmental Neuropsychology, 4(3), 199-230.

Windsor, J., Kohnert, K., Loxtercamp, A., \& Kan, P. (2008). Performance on nonlinguistic visual tasks by children with language impairment. Applied Psycholinguistics, 29(2), 237-268.

Yim, D. S., Jo, Y. J., Han, J. Y., \& Seong, J. M. (2016). Executive functioning skills in Korean-English bilingual children with and without language delay. Communication Sciences \& Disorders, 21(3), 472-487.

Yim, D. S., Park, W. J., Kim, S. Y., Han, J. Y., Song, E., \& Son, J. K. (2019). An eye-tracking study of picture book reading in preschool children with and without language delay. Communication Sciences \& Disorders, 24(2), 299316.

Yim, D. S., Yang, Y. H., \& Kim, S. Y. (2015). Domain-specific working memory performance in children with and without specific language impairment. Communication Sciences \& Disorders, 20(1), 13-23.

Ziethe, A., Eysholdt, U., \& Doellinger, M. (2013). Sentence repetition and digit span: potential markers of bilingual children with suspected SLI? Logopedics Phoniatrics Vocology, 38(1), 1-10.

Zimmerman, I. L., Steiner, V. G., \& Pond, E. (2011). Preschool Language Scales - Fifth Edition (PLS-5). San Antonio, TX: Pearson. 
Appendix 1. English wordlist recall scoring sheet

\begin{tabular}{|c|l|l|l|l|l|l|}
\hline No. & & \multicolumn{1}{|c|}{ 검사문항 } & & \multicolumn{2}{|c|}{ 아동반응 } \\
\hline E1 & 3 & Fell boy hurt & & & \\
\hline E2 & 3 & He wears pants & & & \\
\hline
\end{tabular}

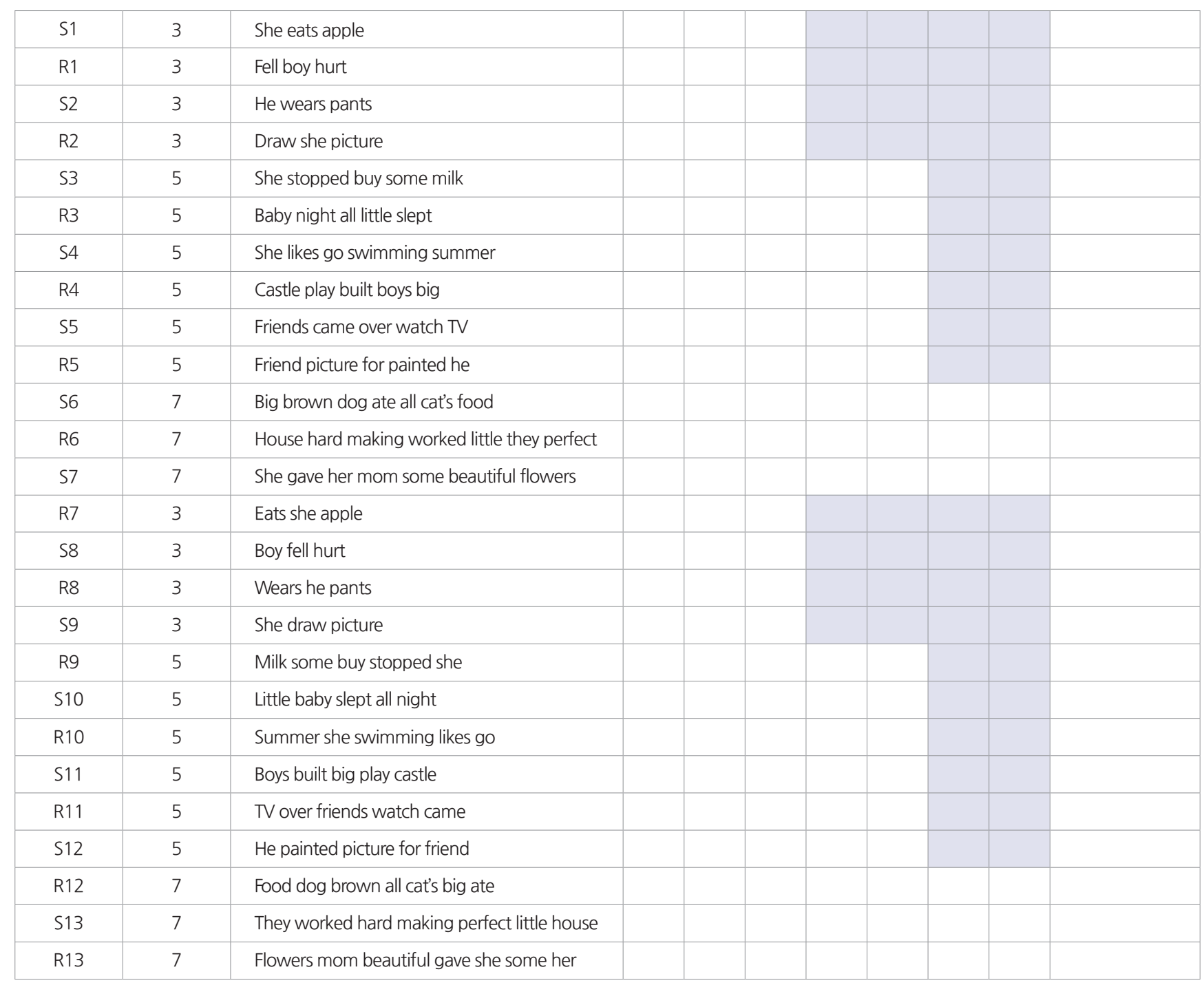




\section{국문초록}

\section{한국어-영어 이중언어 일반아동, 한국어 단일언어 일반아동 및 단순언어장애아동의 덩이짓기(chunking) 능력 비교 조윤주 · 임동선 \\ 이화여자대학교 언어병리학과}

배경 및 목적: 본 연구에서는 한국어-영어 이중언어 일반아동과 한국어 단일언어 일반아동 및 단순언어장애아동의 덩이짓기 능력을 비교하고자 하였다. 방법: 만 4-6세 한국어 단일언어 일반아동 22 명, 한국어 단일언어 단순언어장애아동 16 명, 한국어-영어 이중언어 일반아동 26 명, 총 64 명이 참여하였다. 언어적 덩이짓기 능력을 측정하기 위해 단어목록회상을 사용하였으며, 비언어적 덩이짓기 능력 을 측정하기 위해 대칭-비대칭 매트릭스를 사용하였다. 결과: 한국어 단어목록회상과 대칭-비대칭 매트릭스에서 집단, 자극조건, 기억 폭의 주효과 및 상호작용이 유의하였다. 영어 단어목록회상의 자극조건과 기억폭의 주효과 및 상호작용이 또한 유의하였다. 단일언어 일반아동은 단어목록회상이 어휘력과 상관이 있었으며, 단순언어장애아동은 대칭-비대칭 매트릭스가 상관이 있었다. 반면, 이중언어 일반아동은 단일언어 일반아동과 비교하여 상대적으로 낮은 상관을 보였다. 논의 및 결론: 단순언어장애아동은 두 일반아동 집단과 비교하여 언어적, 비언어적 덩이짓기 과제 모두에서 덩이짓기 능력을 효율적으로 활용하는 데 어려움을 보였다. 이는 작업기억과 장기 기억, 언어처리시스템을 통합하는 일화적 완충기 능력이 더 낮은 것으로 보이며 이러한 차이가 이들의 어휘력의 어려움과 관련이 있는 것으로 보인다. 한편 이중언어와 단일언어 일반아동 집단 간 수행력에는 통계적으로 유의한 차이가 나타나지 않았는데, 이는 정상발달 아동의 덩이짓기 능력이 언어 기저의 처리과정을 반영하기 때문에 이중언어 사용유무의 영향을 받지 않는 것으로 해석할 수 있다.

핵심어: 덩이짓기, 작업기억, 일화적 완충기, 이중언어, 단순언어장애

본 논문은 2019년 대한민국 교육부와한국연구재단의 지원을 받아수행된 연구임(NRF-2018S1A3A2075274).

\section{참고문헌}

김영태, 홍경훈, 김경희, 장혜성, 이주연(2009). 수용·표현어휘력검사(Receptive \& Expressive Vocabulary Test, REVT). 서울: 서울장애인종합복지관. 문수백, 변창진(2003). K-ABC 교육심리측정도구(Korean -Kaufman assessement battery for children: K-ABC). 서울: 학지사. 안지숙, 김영태(2000). 단순언어장애 아동과 정상아동의 구문적 난이도에 따른 문장 따라말하기: 수행력 및 명료도 비교. 음성과학, 7(3), 249-262. 임동선, 박원정, 김신영, 한지윤, 송은, 손진경(2019). 그림책 읽기에서 일반아동 및 어휘발달지연 아동의 이야기 이해 능력 및 안구 운동 패턴 분석: 시 선추적기 연구. Communication Sciences \& Disorders, 24(2), 299-316.

임동선, 양윤희, 김신영(2015). 단순언어장애 아동과 일반 아동의 작업기억 제시방식 및 과제유형에 따른 수행능력 비교. Communication Sciences

\& Disorders, 20(1), 13-23.

임동선, 조연주, 한지윤, 성지민(2016). 한국어-영어 이중언어사용 아동의 어휘발달지연 유무에 따른 집행기능 비교. Communication Sciences \&

Disorders, 21(3), 472-487.

천소연, 임동선(2017). 단어목록 회상을 통한 언어발달지체 아동과 일반아동의 덩이짓기 능력 연구. Communication Sciences \& Disorders, 22(2), 233-244.

홍성미, 임동선(2014). 학습 및 기억과제를 통한 이중언어 아동의 언어발달지체 평가. Communication Sciences \& Disorders, 19(1),31-44. 홍현주, 임동선(2014). 단순언어장애 아동의 작업기억 하위체계와수용어휘능력 간의 관계. 언어치료연구, 23(2), 35-44.

\section{ORCID}

조윤주(제1저자, 석사과정 https://orcid.org/0000-0001-7526-0358); 임동선(교신저자, 교수 https://orcid.org/0000-0001-8254-9504) 